\title{
How the Elephant Lost His Tusks
}

\author{
Andrew J. Heimert
}

"When we are hungry, elephants are food. When we are full, elephants are beautiful.",

The elephant is surely one of the most widely liked animals. Despite this general popularity, the number of African elephants has declined significantly in recent years. This Note explores two alternative strategies that African nations have employed in their attempts to halt the decline of elephant populations. Each strategy is an effort to restrict access to the proverbial "commons." One method, used in Kenya, attempts to maintain elephant populations by ensuring absolute protection from poachers and by banning all trade in elephants. The other approach, used primarily in southern Africa-including Zimbabwe and South Africa-actively manages elephant populations, culling some animals in order to provide sufficient habitat and protection for the remaining ones. The southern African countries share proceeds earned from wildlife with local people, in effect creating a form of property rights in elephants. This Note argues that the current international ban on ivory trade harms the latter kind of program, which has been more effective at protecting elephants.

Poaching and habitat destruction as a result of human encroachment are the two primary threats to the elephant. ${ }^{2}$ These twin forces have reduced African elephant $t^{3}$ populations from an estimated $1,300,000$ in 1979 to 609,000 in $1989 .^{4}$ This Note assumes that there is, and will continue to be, an

1. Edward R. Ricciuti, The Elephant, WILDLIFE CONSERVATION, Mar.-Apr 1993, al 14. 19 (quoung Zimbabwean farmer).

2. See RAYMOND BonNer, AT THE HAND OF MAN 265 (1993) ("The reality of Afnca is the expanding human populations, with the attendant pressures on land."): Michael J. Glennon. Has International Law Failed the Elephant?, 84 AM. J. INT'L L. 1. 2 (1990); Tom Opre, Using Africa's Wildlife Only Way To Save It, DET. FreE PRESS, Nov. 5, 1989, at 4E ("Africa's biggesi single problem is a human populauon growing at a rate nearly unsurpassed elsewhere in the world."); Rucciutu, supra note 1, al 18 ("[Elephants') range has been constricted and fragmented, mainly due to people and their enterpnses.")

3. The subject of this Note is Loxodonta afncana, the Afncan elephant. The Asian clephant. Elkphos maximus, is not considered herein. Technically. there are two subspecies of Laxodonta africana: La. africana, the bush and savannah elephant, and La. cyclotis. the forest elephant. See Lee J T. White. The Other African Elephant, WiLDLIFE CONSERVATION, Mar-Apr. 1993, at 50. 51

4. David Concar \& Mary Cole, Consenatron and the lvon Tower. New SCIENTIST, Feb. 29. 1992. at 29,30 . Other estimates differ. See. e.g. BONNER, supra note 2. at 89.92 (repontung population decrease from one million in 1981 to 700,000 by 1988). Elephant population statustics are not particularly reliable. See generally Jonathan S. ADAMS \& ThOMAS O. MCSHANE, THE MYTI OF WILD AFRICA 74 (1992) (discussing difficulties of counting elephant populations). 
economic value for elephants, both from tourism as well as from tusks, hides, and meat. A demand for elephant products creates an economic value for those products, ${ }^{5}$ which in turn leads to trade in those products. A substantial amount of illegal animal trade currently exists ${ }^{6}$ and is unlikely to dissipate. Therefore, it is unlikely that an international trade ban, such as the Convention on International Trade in Endangered Species of Wild Fauna and Flora (CITES), will stem the flow of such products to parts of the world where demand still exists. ${ }^{8}$ The removal of hide and tusks necessitates killing the elephant, ${ }^{9}$ but elephants would be killed even without the demand for elephant products. Because elephants are a danger and a nuisance to farmers and families, they are often viewed as pests to be exterminated. These sentiments clearly conflict with the desire for live elephants for tourism, other utilitarian goals, or moral reasons. ${ }^{10}$

5. David S. Favre, Debate Within the CITES Community: What Direction for the Future?, 33 NAT. RESOURCES J. 875, 888 (1993) ("The retail demand creates economic value for wildlife-alive, dead or as products-and therefore creates an incentive for illegal activity.").

6. John H. Cushman, Jr., World Group To Debate Plan To Protect Species by Numbers, N.Y. TIMES, Nov. $6,1994, \S 1$, at 44 (reporting estimated $\$ 5$ billion annual illegal trade in endangered species); Favre, supra note 5 , at 888 (noting estimates of $\$ 100$ million worth of animals and plants illegally smuggled annually into United States).

7. The Convention on International Trade in Endangered Species of Wild Fauna and Flora, opened for signature Mar. 3, 1973, 27 U.S.T. 1087, 993 U.N.T.S. 243 [hereinafter CITES]; see infra part I.A.

8. Alastair Bradstock, Elephant Saviours in Ivory Towers, GEOGRAPHICAL MAG., Dec. 1990, at 14, 14 ("The ban's success rests on the assumption that by stopping the trade the demand for ivory will decline."). This demand, however, is unlikely to disappear. See BONNER, supra note 2, at 52 (noting increasing demand in Japan for ivory, because of increased wealth and desire to obtain status symbols); DAVID S. FAVRE, INTERNATIONAL TRADE IN ENDANGERED SPECIES 140 (1989) ("II]n several cultures ivory has long been in demand for medical, fertility or religious purposes."); Bradstock, supra, at 14 (noting United Nations report suggesting too great investment in ivory business for demand to disappear); $c f$. DEREX WILSON \& PETER AYERST, WHITE GOLD 177 (1976) (noting that ivory, like precious metals and gems, acts as hedge against inflation); Favre, supra note 5, at 888 ("There are [those] who have a desire to possess the unique, and many do not care whether they obtain the items legally or illegally.").

David Harland says that the ivory trade ban effectively eliminated American and European demand for ivory, but posits that Asian countries continue to demand ivory, primarily because they are relatively unconcerned about wildlife conservation. DAVID HARLAND, KILLING GAME: INTERNATIONAL LAW AND T7IB AFRICAN ELEPHANT 54 (1994). He also presents statistics suggesting that it is most critical to stop demand in Asia, because Asia is responsible for $88 \%$ of global consumption of raw ivory. Id. at 36.

9. "The only practical way of removing ivory from an elephant is by killing it." HARLAND, supra note 8, at 21. Even if one were able to take the ivory from an elephant without killing it, elephants need their tusks for survival. See BONNER, supra note 2, at 106 (noting that elephants use their tusks to glean food from trees); CyNTHIA Moss, Elephant MEMORIES: THIRTEEN YeARS IN THE LifE of AN ElEPHANT FAMILY 291 (1988) (noting that elephants use tusks "for feeding, digging, poking, playing and fighting"): Ricciuti, supra note 1, at 21 ("Tusks are indispensable-and are used to dig up roots, untangle trce branches, and drill dry riverbeds for water. They are also used as weapons, in display, and as 'bumpers' for the elephant's trunk."). Elephants grow only one set of tusks in a lifetime. HARLAND, supra note 8, at 21.

10. This Note does not explore exhaustively the morality of the different programs; nevertheless, there are important ethical concerns. One of the objections to active management (also known as sustainable utilization) is that it requires killing individual animals, even if it does protect the species. This argument involves debates about whether individual animals have rights that humans must recognize, or whether it is the species that has a right to survival. Favre poses the critical question, which is whether elephants have their own interests as social animals or whether they are "merely large turnips, to be harvested and consumed." Favre, supra note 5, at 880 . Because of the absence of a consensus on the moral issue and the insufficiency of funds to protect elephants, this Note focuses on how best to protect as large a population 
In recent years, much of the debate over the elephant has focused on the level of protection international law will extend to the species. The development of international law to protect the elephant, and the structure of CITES in particular, is examined in Part I of this Note. Par II describes the method that Zimbabwe and South Africa have used in attempts to preserve their elephant stocks and contrasts those schemes with the method used in Kenya. The Note then examines the results each country has achieved in recent years and suggests that the southern African active management programs have been more effective.

Numerous scholars have described multitudinous variations on commons problems. Part III applies the theoretical "commons" model to the elephant. This Part analogizes the elephant to marine and other natural resources and uses solutions to standard commons problems to explain the relative efficacy of Zimbabwe's active management policy for elephants. Part IV illustrates that a democratic government better fosters preservation of elephants through electoral incentives than does an undemocratic government. A democratic government is less likely to be corrupt than an undemocratic government, and so is less likely to allow poaching to continue. Despite similarities between South Africa's and Kenya's management programs, because South Africa's government has faced more electoral competition than Kenya's government. South Africa has avoided the adverse effects that corruption has had on Kenya's elephant population.

Part $\mathrm{V}$ addresses the results of other bans on trade in wildlife and draws parallels to the ban on trade in elephant products. In particular, the strict limitations on trade in leopard skins illustrate the possibility of a manageable system of limited trade in valuable animal parts. This Part concludes that limited trade in ivory could successfully be reopened, particularly in light of recent ivory identification processes.

\section{THE TREATMENT OF THE ElephaNT IN INTERNATIONAL LAW}

The declining population of numerous species of wildlife in recent decades has drawn much international attention. To address this problem, several nations, including the United States, created CITES." CITES became effective on July 1,1975 , and has since been joined by at least 122 nations. ${ }^{12}$ The agreement's general purpose is to save plants and animals that are becoming extinct from overexploitation as a result of international trade. ${ }^{13}$

\footnotetext{
of elephants as is affordable.

11. CITES, supra note 7.

12. See Cushman, supra note 6 , at 44.

13. See CITES, supra note 7. pmbl., 27 U.S.T. at 1090.993 U.N.T.S. at 244
} 


\section{A. The Structure of CITES}

CITES divides species into tiers of protection based on the degree to which they are threatened with extinction. ${ }^{14} \mathrm{~A}$ species may be listed in one of three appendices. Appendix I includes "all species threatened with extinction which are or may be affected by trade."15 Appendix II comprises animals that require regulation in their trade to avoid becoming endangered. ${ }^{16}$ When a nation deems a species' survival within its own borders to be in jeopardy, it may enlist international cooperation by placing the species on Appendix III. ${ }^{17}$

The Convention requires different levels of protection by mandating trade restrictions for species in each of the appendices. ${ }^{18}$ In order to trade species listed in Appendix I, both the importing and exporting nations must issue a permit for a specific transaction. ${ }^{19}$ The permit signifies that both trading states have determined that the import or export is not "detrimental to the survival of the species involved."20 The importing country must also determine that the specimen "is not to be used for primarily commercial purposes."21 Even trade that does not affect the survival of the species is often prohibited. For example, trade of hides from endangered animals that have died of natural causes is unlawful. ${ }^{22}$ The overall goal is to subject species listed on Appendix I to "particularly strict regulation"23 and thereby effectively eliminate trade in those animal products. ${ }^{24}$

14. See id. art. II, paras. 1-3, 27 U.S.T. at 1092, 993 U.N.T.S. at 245-46.

15. Id. art. II, para. 1, 27 U.S.T. at 1092, 993 U.N.T.S. at 245 . Trade in the animal and its derivative products is prohibited. Id. art. I, cl. b(ii), 27 U.S.T. at 1090, 993 U.N.T.S. at 245.

16. Id. art. II, para. 2, cl. a, 27 U.S.T. at 1092, 993 U.N.T.S. at 245.

17. Id. art. II, para. 3, 27 U.S.T. at 1092, 993 U.N.T.S. at 246. Under Appendix III, trade is restricted only with the country that has deemed its own population of a species to be endangered. FAVRE, supra note 8 , at 140 .

18. CITES, supra note 7, art. I, cl. b(i)-(ii), 27 U.S.T. at 1090, 993 U.N.T.S. at 245 (defining "specimen" as any animal or plant, dead or alive, and any "recognizable part or derivative thercof"). This Note uses the term "trade in the species" to include all trade involving products made from the species, not just live specimens.

19. Id. art. III, paras. 2-3, 27 U.S.T. at 1093-94, 993 U.N.T.S. at 246.

20. $1 d$.

21. Id. art. III, para. 3, cl. c, 27 U.S.T. at 1094, 993 U.N.T.S. at 246 . This does not prohibit all transactions that involve money. For example, a research institute might purchase a live specimen from another country, subject to the other requirements of CITES. FAVRE, supra note 8, at 82. Zoo purchases have presented a conundrum, because there is often a mixed purpose of scientific inquiry and profitecring from the exhibition of rare animals. To counter potential objections, some of the additional profits from the display of such animals, like the panda, may be used to further the survival of the species. Id. at 85-86.

22. The ban theoretically eliminates the incentive for humans to induce premature elephant deaths by failing to provide adequate habitat, or through other indirect methods. Advocates of the ban suggest that it would be difficult to distinguish between legitimate trade and illegitimate trade, and argue that to permit any trade would allow illegal trade to continue. BONNER, supra note 2, at 147 . The complete commercial trade ban was implemented in part to counter anticipated political and economic pressure on governments that would jeopardize a partial ban. Favre, supra note 5, at 906-07. This problem might be cured by some form of marking system. See infra text accompanying notes 250-51, 255.

23. CITES, supra note 7, art. II, para. I, 27 U.S.T. at 1092, 993 U.N.T.S. at 245.

24. Glennon, supra note 2 , at 11 . 
Appendix II provides a lower level of protection than Appendix I, allowing regulated commercial trade in the species listed therein. ${ }^{25}$ To impor a species, only an export permit from the exporting country's scientific authority is required. ${ }^{26}$ Trade in Appendix $I I$ species is monitored by parties to CITES in order to ensure that sufficient numbers of a species remain in their habitat, and to decide if an Appendix I listing might be more appropriate. ${ }^{27}$ Appendix II permits commercial trade in animals to continue. Species are listed in Appendix I or II through a vote of the signatory parties at one of the biannual conferences required by CITES. ${ }^{28}$

The CITES treaty allows a country to take a reservation-or effectively to opt out of the listing of a particular species-either upon joining CITES ${ }^{29}$ or when there is an amendment to the appendices concerning that species. ${ }^{30}$ If a country takes a reservation, the country is exempted from the Convention for that species. ${ }^{31}$ A reservation therefore allows a country to trade animal products freely with countries that either are not a party to CITES or have taken a reservation. ${ }^{32}$ The initial intent of the reservation process was to protect domestic industries that relied upon the species. ${ }^{33}$ The reservation process, however, created a loophole through which products of protected species can be "laundered." Some states with reservations receive the products and process them into final goods that are considered permissible for trade purposes. ${ }^{34}$ Because the products must be a "readily recognizable part" the protected animal, trade in ivory, for example, is no longer prohibited once it has been carved. ${ }^{36}$ In sum, use of the reservation process can limit the efficacy of an Appendix I ban.

25. Id.

26. CITES, supra note 7, ar. IV, para. 2, cl. a. 27 U.S.T. at 1095, 993 U.N.T.S. at 247.

27. Id. art. IV, para. 3, 27 U.S.T. at 1095-96, 993 U.N.T.S. at 247.

28. Id. art. XI, para. 2 \& para. 3, cl. b. 27 U.S.T. at $1104-05.993$ U.N.T.S. at 251.

29. Id. art. XXIII, para 2, cl. 2, 27 U.S.T. at 1116, 993 U.N.T.S. at 257.

30. Id. art XXIII, para. 1, 27 U.S.T. at 1116, 993 U.N.T.S. at 257; id. art. XV. para. 3. 27 U S.T. at 1112,993 U.N.T.S. at 255.

31. Id. art. XXIII, para. 3, 27 U.S.T. at 1116, 993 U.N.T.S. at 257.

32. FAVRE, supra note 8 , at 323.

33. Id.

34. Id. at 323-24. For a brief description of how some countries have laundered elephant tusks to avoid CITES, see BONNER, supra note 2, at 96.

35. CITES, supro note 7, art. I, cl. b(ii), 27 U.S.T. at 1090. 993 U.N.T.S. at 245. Theoretucally any product made or taken from a dead animal, such as the hide or tusk of an elephant, is included in the restrictions on trade. Until 1988, however, carved ivory was not considered a recognizable par of the elephant, and thus was not subject to regulation under CITES. FAVRE, supra note 8, al 126. After 1988, new CITES regulations required carved ivory to be accompanied by the same importexpon permits required of uncarved ivory. Id. at 134.

36. FAVRE, supra note 8, at 324; Glennon, supra note 2 , at 12. 


\section{B. CITES and the Elephant}

The African elephant was placed on Appendix II in $1977 .{ }^{37}$ Subsequent population surveys in the late 1970's and early 1980's revealed the continuing drop in elephant populations. ${ }^{38}$ The sustained decline led to the development of the Ivory Export Quota System (IEQS) at the 1985 CITES convention. ${ }^{39}$ IEQS required each ivory-exporting state to determine the number of elephant tusks that it could export each year ${ }^{40}$ and to mark each tusk with its country of origin and a unique code number. ${ }^{41}$ The system created a database that would assist customs agents in determining which countries could legally export ivory within their quota. ${ }^{42}$ The primary goal was to ensure that a country accepting ivory for import actually ascertained that a valid export permit had been granted for that ivory. ${ }^{43}$

The theory of the IEQS was better than its practice. Because each country was permitted unilaterally to determine its quota, a country was not bound by any scientific or international estimates of the sustainable number of elephant culls. The quotas of some countries had no basis in reality. For example, Somalia set its 1986 quota at 17,000 tusks, despite an estimated elephant population of only 6000 . Raymond Bonner explains that Somalia was actually planning to export tusks illegally taken in Kenya. ${ }^{44}$ It was soon determined that the quota system was not achieving its goal, ${ }^{45}$ and the international community recognized that further action was necessary to save the elephant.

In 1989, the CITES conference banned all trade in ivory by moving the African elephant from Appendix II to Appendix I. Earlier that year, the United States and several European countries unilaterally had imposed sweeping bans on ivory imports, ${ }^{46}$ and the African Wildlife Foundation and World Wide

37. FAVRE, supra note 8 , at 125.

38. BONNER, supra note 2, at 51 ; see Ricciuti, supra note 1 , at 17 ; supra note 4 and accompanying text.

39. Glennon, supra note 2, at 12; see also FAVRE, supra note 8, at 127-37.

40. FAVRE, supra note 8 , at 127 . The elephant population can increase despite culling so long as culls are limited to elephants beyond their reproductive years and to smaller numbers of elephants than are bom into a population. BONNER, supra note 2, at 96. In the absence of outside interference, clephants' reproductive rate normally exceeds the death rate from natural causes. See ADAMS \& MCSHANE, supra noto 4, at 83 (noting resiliency of elephant populations in Addo, a protected elephant enclave in South Africa). Protected elephant populations grow at $4.5 \%$ to $5 \%$ per year. Jane Perlez, African Wildlife Parks: Is Less Wild the Way of the Future?, N.Y. TIMES, Jan. 23, 1990, at C4; see also HARLAND, supra note 8, at 19 (reporting 6\% elephant population growth under ideal conditions).

41. FAVRE, supra note 8, at 129.

42. Id. at 127-29.

43. Id. at 130.

44. BONNER, supra note 2, at 96 .

45. Some analysts contend, however, that the IEQS was never given a real chance to work. Id. at 143; cf. infra text accompanying notes 250-55.

46. BONNER, supra note 2, at 34; see, e.g., African Elephant Conservation Act, 16 U.S.C. $\$ \S 420 \mathrm{I}-4245$ (1988) (authorizing conservation expenditures; banning most ivory imports; providing criminal penalties for violations). The Act authorizes the Secretary of the Interior to ban ivory imports from nations that are determined to have ineffective elephant preservation programs. Id. $\S 4222$. 
Fund for Nature had expressed support for a full international ban on trading. ${ }^{47}$ East African nations, where elephant populations had been plummeting, ${ }^{48}$ supported the ban. ${ }^{49}$ In contrast, the southern African countries, where elephant populations were increasing or remaining stable, opposed the ban. ${ }^{50}$ The proposed amendment was passed over the opposition of the southern African countries, which nevertheless took reservations. Because no major ivory-purchasing nations took reservations there was no opportunity for significant legal sales to CITES signatories."

The 1992 CITES conference renewed the debate on Appendix I's terms. The group of countries favoring sustainable utilization, including Zimbabwe, attacked the complete ban and sought to allow countries with effective active wildlife management programs to sell elephant parts. ${ }^{52}$ The group's proposal would require use of revenues earned from "beneficial use" of wildlife to provide additional money to "rural wildlife-producer communities," to "further invest in wildlife development," or to "provide income at a national level to developing countries." 53 The proposed changes were rejected. ${ }^{54}$

International efforts to protect the elephant have consisted of progressively tighter controls on the trade of its derivative products culminating in a total trade ban. These policies, however, have failed to eradicate either consumers' demand $^{55}$ for elephant products or the supply ${ }^{56}$ of elephant ivory. Similarly, there have been few concerted international efforts to increase actual protection of the elephant by funding tighter antipoaching enforcement aimed at constraining ivory supply. The CITES ban was essentially an international mandate for African countries to act. ${ }^{57}$

\footnotetext{
47. BONNER, supra note 2 , at 34 .

48. Id. at 91 .

49. Id at 129. But see id. at 92 (suggesting some Kenyans opposed ban).

50. Id. at 91-92 (including Botswana. South Africa, and Zimbabwc).

51. Michael Sutton, World Wildlife Fund, Lecture at Yale Law School (Apr. 12, 199.4).

52. Favre, supra note 5, at 903.

53. Id. at 903 n.106.

54. Id. at 904 .

55. A law alone is unlikely to eliminate consumer demand. See supra note 8: of. The Wages of
} Prohibition, ThE ECONOMIST, Dec. 24, 1994-Jan. 6, 1995, at 21, 21 (noting failure of U.S. drug laws to stop cocaine use or trafficking).

56. Supply, in this Note, means the supply of ivory and other elephant products, rather than the supply of live elephants. Thus, protecting elephants presumably increases the supply of elephants, while diminishing the supply of ivory and other elephant products.

57. The ban involves imporant national sovereignty issues. One author notes. "As many Africans see it, white people are making rules to protect animals that white people want to see in parks that white people visit." BONNER, supra note 2, at 85; see also John Waithaka, The Elephant Mfenace. WILDLIFE CONSERVATION, Mar-Apr. 1993, at 62,62 ("Government wildlife policies were instituted in such a way that people who had killed ... wildlife products for income were treated as poachers. Local people. then. felt denied the use of resources that they considered to be theirs."). One estimale suggesied that the ban amounted to a $\mathbf{\$ 5 0}$ million tax on African nations in the form of lost revenue from ivory. BONNER, supra note 2 , at 142 .

Michael Glennon has developed a theory of a global environmental right that allows all nations to expect that an endangered species will be preserved by the nation in which that species exists. Glennon. supra note 2, at 34-35. Glennon argues that his global environmental right gives rise to a corresponding 


\section{The Two MANAgEMENT SCHEMES}

African countries must reconcile the tension between the incentives to preserve elephants and the incentives to reap value from dead elephants. Live elephants can generate tourism revenue $e^{58}$ and produce additional elephants. Substantial value can also be derived, however, from elephant products. Ivory was worth over $\$ 100$ per pound in $1989,,^{59}$ meaning that a single elephant could carry more than $\$ 1000$-worth of ivory. ${ }^{60}$ Further, the hides and meat are valuable, $^{61}$ and a trophy hunt for an elephant commands a high price. ${ }^{62}$ Hunters' expenditures on such hunts far exceed the cost of the license required by the government, bringing additional money to an area. Elephant preservation, therefore, imposes substantial opportunity costs on a community.

There are also real costs to retaining elephants. In Zimbabwe, elephants have been known to destroy crops and to kill people. ${ }^{63}$ Elephants damage buildings, destroy water pipes, kill livestock, ${ }^{64}$ and are generally considered to be pests. ${ }^{65}$ Experiences in Kenya have been similar. ${ }^{66}$ Thus there is an

global environmental obligation, which makes it incumbent upon all nations to support financially the efforts of a country attempting to preserve a species. Id. at 35 . Nonetheless, large-scale monetary support has not been forthcoming. BONNER, supra note 2, at 142 . Glennon leaves unresolved whether the right may be claimed if the obligation goes unmet.

Favre writes, "[CITES] is based upon 1960's perceptions of wildlife issues, as seen by North American and European drafters. . . . Many of the developing countries have a different perspective about wildlife management arising out of their own philosophy, economic reality and social needs." Favre, supra note 5 , at 876 .

58. BONNER, supra note 2, at 219 (reporting estimate by contingent valuation that preservation of elephants for viewing was worth $\$ 100$ per tourist); Ricciuti, supra note 1 , at 33 (reporting that Kenya Wildlife Service estimates it earns $\$ 420$ million per year from wildlife tourism). But see id. at 33-34 (noting that most countries could not approach Kenya's sizable tourism trade).

59. Glennon, supra note 2, at 26; see also HARLAND, supra note 8 , at 37 (noting price of $\$ 135$ per pound at pre-ban peak in 1989); Ricciuti, supra note 1, at 18 (same); cf. Richard E. Leakey, A Perspective from Kenya: Elephants Today and Tomorrow, WILDLifE ConSERVATION, Mar-Apr. 1993, at 58, 58 (citing pre-ban price of $\$ 140$ per pound). The post-ban price is less certain, but estimated to be about $\$ 5$ per pound. Id. But compare id. with Killing a Giant for Its Teeth, NEWSWEEK, Nov. 28, 1994, at 8 (comparing elephant ivory price of $\$ 225$ per pound to $\$ 30$ per pound price of hippopotamus-tooth ivory).

60. See Glennon, supra note 2 , at $10 \mathrm{n} .74$ (reporting that elephant tusks declined from 15-20 pounds to an average of 7 pounds by 1990); see also HARLAND, supra note 8, at 37 (noting decline of average tusk weight to 10 pounds in 1987). Another writer reports $\$ 3600$ as the gain for the middleman or final exporter from an elephant. Leakey, supra note 59, at 58.

61. Randy Simmons \& Urs Kreuter, Save an Elephant-Buy Ivory, WASH. PosT, Oct. 1, 1989, at D3 (noting hides worth $\$ 2000$ each).

62. BONNER, supra note 2, at 268 (noting that Zimbabwe charged $\$ 3750$ per elephant hunting license in 1989); Brian Child, The Elephant as a Natural Resource, WILDLIFE CONSERVATION, Mar.-Apr. 1993, at 60,61 (reporting trophy prices up to \$12,000); Bill Keller, Splat! Splatl This Elephant "Kill" Is a Paint $J o b$, N.Y. TiMES, Sept. 20, 1994, at A4 (reporting trophy fee of \$6000); see also id. at A4 (reporting elephant "hunts" costing $\$ 750$, in which elephant is shot with paint gun); $c f$. BoNNER, supra note 2, at 241 (noting substantial potential value that limited hunting would have for countries).

63. Jerelyn Eddings, Overabundant Elephants Make Out Like Pigs, or Simply Giant Pests, in Zimbabwe, L.A. TIMES, Jan. 12, 1992, at A7; Ricciuti, supra note 1, at 18 (noting 500 Zimbabweans killed by elephants between 1982 and 1989).

64. Michael Satchell, Wildlife's Last Chance, U.S. NEwS \& WORLD REP., Nov. 15, 1993, at 68, 68.

65. Eddings, supra note 63 , at $\mathbf{A 7 .}$

66. Waithaka, supra note 57, at 63. Rampaging elephants have reportedly destroyed harvests; disrupted schools; damaged barns, trees, dams, trenches; and killed livestock and people. Id. A survey revealed that 
understandable desire on the part of local people to eliminate the threat posed by elephants. Given Africa's increasing competition for land use, ${ }^{67}$ retaining the native peoples' desire to preserve the elephant is a particularly important part of any solution. ${ }^{68}$

Elephant protection is expensive: Estimates suggest the expenditure required to protect a square kilometer of elephant habitat is over $\$ 200$ per year. ${ }^{69}$ One source estimates Africa's cumulative wildlife protection costs at $\$ 305$ million. $^{70}$ Another estimate placed Africa's cost to protect only elephants inside of parks and preserves at $\$ 100$ million per year." Total annual expenditures for elephant protection throughout Africa are currently about $\$ 50$ million. $^{72}$ African nations must, therefore, raise more funds for elephant protection if the elephant is to survive.

Zimbabwe and Kenya have approached the problem of preserving elephant populations differently. Zimbabwe, like South Africa, relies on profits from elephants to support its wildlife management program. ${ }^{33}$ Zimbabwe's policy grants a share of elephant proceeds to local people. This policy allows the local population to share in the value of elephants and to appropriate that value for antipoaching patrols, various measures to protect and manage the elephant population, and other local needs. Zimbabwe sought to operate within the constraints of an Appendix II listing (until the elephant was moved to Appendix I), determining that its exports of elephant products did not cause a decline in elephant numbers within its borders. Since the ban, Zimbabwe has relied on remaining methods of profiting from elephants, such as trophy hunts, to augment funding for protection programs.

Kenya bans all hunting of elephants ${ }^{74}$ and sales of elephant products. ${ }^{75}$

97\% of peasant farmers in one area strongly dislike elephants and nearly all had substanual crop losses to elephants. Id.; see also BONNER, supra note 2, at 214 (noting significant crop loss to clcphants)

67. See supra note 2 and accompanying text.

68. African tribes are frequently conservationist as part of their culture, reflectıng their dependence upon wildlife. BONNER, supra note 2, at 82 . Nevertheless, many conservationist altempis in recent years have been viewed as imperialistic or colonialist because the programs have not involved local populations. Id. at 85; see also supra note 57. The problem is thus not one of changing local attitudes, but rather of involving local populations and providing proper incentives.

69. BONNER, supra note 2, at 93-94 (reporting that conservatuonist estimates place cost between \$200 and $\$ 400$ per square kilometer, assuming sufficiently high ranger salanes to avold comuption. and enough money for one ranger per $50 \mathrm{~km}^{2}$ ).

70. Concar \& Cole, supra note 4, at 31 .

71. ADAMS \& MCSHANE, supra note 4, at 170-7! (presenting view's of Rowan Martin. Zimbabwe's Director of Department of Parks and Wild Life Management).

72. Id. at 171 .

73. BONNER, supra note 2, at 91-92. Note that Malawi. Namibia. and Zambia also suppon sustanable utilization. Peter Aldhous, Critics Unge Reform of CITES Endangered List, 355 Nature 758. 758 (1992). Zambia has temporarily withdrawn its support for jvory trade because it has been unable to control poaching. B.J. Kelso, Hunting for Conservation, AFR. REP., July-Aug. 1993, at 68. 71.

74. The Wildlife (Conservation and Management) (Prohibition on Huntung of Game Animals) Regulations, 30 Kenya Gazette Supp. (May 20, 1977) (banning all game animal hunung). For Kenyan legislation relating to the protection, conservation, and management of wildlife, see generally The Wildlife (Conservation and Management) Act, No. 1 of 1976, 8 Kenya Gazelte Supp. (Feb. 13. 1976). 
Kenya implemented its prohibition on the sale of elephant products prior to the international trade ban, but it generally emulates the CITES Appendix I stipulations. Kenya's method combines antipoaching patrols with a domestic trade ban in order to preserve and protect its elephants.

Each scheme may be described generally as a management plan: Kenya manages the elephant population by prohibiting trade in elephant products, while Zimbabwe manages it by providing monetary incentives to local groups that actively help to protect the elephant population from poachers. Zimbabwe's plan is frequently termed sustainable utilization. Because Zimbabwe's approach contemplates active management of the elephant population, this Note refers to it as a "management strategy." The Kenyan system, which focuses on elephant protection, is referred to as a "protective strategy."

\section{A. Active Management Strategies}

Zimbabwe's management plan operates on the premise that "African wildlife, if it is to survive in the long run, must pay its way." ${ }^{\prime 76}$ Before the Appendix I ban, the Zimbabwean government spent up to $\$ 15$ million per year for all of its wildlife protection, ${ }^{77}$ using money generated by wildlife trade to pay for its protection. Since the elephant was switched to Appendix I, Zimbabwe has reduced its expenditures to $\$ 5.5$ million. $^{78}$ International contributions, estimated at $\$ 500,000$ per year, do not compensate for this shortfall in funding. ${ }^{79}$ Zimbabwe's government is hard-pressed to increase funding, given the competing desires for health care and schools. ${ }^{80}$ Because African and foreign governments and conservationist groups are unwilling or unable to pay for elephant preservation, Zimbabwe has maintained that it should be allowed to sell elephant products in order to fund elephant protection. It believes that revenue from tourism and the sale of elephant products would provide several million dollars that could be used for conservation efforts. ${ }^{81}$

75. The Wildlife (Conservation and Management) (Revocation of Dealer's Licenses) Act, No. 5 of 1978,35 Kenya Gazette Supp. (June 23,1978 ) (revoking all licenses to trade in wildlife products).

76. Concar \& Cole, supra note 4 , at 29.

77. See ADAMS \& MCSHANE, supra note 4, at 170.

78. Remer Tyson, Herds Pay Highest Price-Ivory, Horn Ban Is Under Fire as Poaching Plagues Africa, DET. FREE PRESS, Mar. 8, 1993, at A1.

79. ADAMS \& MCSHANE, supra note 4, at 170; see BONNER, supra note 2, at 158 (noting that pledges to help Africa combat this problem totaled about $\$ 8.5$ million for all of Africa in 1989); see also id. at 142 (reporting one estimate that ban effectively imposed approximately $\$ 100$ million cost on African nations without compensation).

80. See BONNER, supra note 2, at 93 (describing how impoverishment of many African states precludes high expenditures necessary for adequate wildlife protection); Child, supra note 62, at 61 (rural family of eight has average income of $\$ 150)$.

81. BONNER, supra note 2, at 107 (noting that prior to ban, Zimbabwe's "thriving domestic carving industry" earned $\$ 2$ million per year from sale of ivory gleaned from culls, and that some of this revenue 
Zimbabwe has allowed local people to manage wildlife in their area for two decades, since the Rhodesian government passed the Parks and Wild Life Act. $^{82}$ The Act gave landholders both the responsibility for, and the use of, animals on their land. ${ }^{83}$ In 1982 , Zimbabwe developed a program pursuant to the Act called CAMPFIRE (Communal Areas Management Programme for Indigenous Resources). CAMPFIRE asks local people to manage their wildlife resources, ${ }^{84}$ on "the premise that the wildlife belongs to the person on whose land it is found." ${ }^{85}$ Beginning in 1989, Zimbabwe Trust, a local nonprofit development organization, allocated funds to the Nyaminyami district and the CAMPFIRE program. ${ }^{86}$ The program turned over to the district council of Nyaminyami, a communal land area in northwestern Zimbabwe, ${ }^{87}$ the means to manage local wildlife resources. ${ }^{88}$ This involves giving local people technical assistance in managing the wildlife. ${ }^{89}$ Each year a census of the local elephant population is submitted to the national wildlife department. ${ }^{90}$ After this count is verified, the local council is given a quota of $1 \%$ of the elephants to hunt or cull as the council's needs dictate."

In 1989, the Nyaminyami area of Zimbabwe earned enough from the sale of wildlife products (not just elephants) to support its conservation at a level well above the norm, ${ }^{92}$ and to support its purchases of otherwise unaffordable social services. ${ }^{93}$ Before the trade ban, residents earned profits from the sale of hides and ivory. ${ }^{94}$ Since ivory sales are now banned, Zimbabwe has relied

went into general treasury and ultimately to country's parks and conservation departments): Child, supra note 62 , at 61 (noting pre-ban income of $\$ 2$ million, $40 \%$ from trophy elephants): Ricciut!. supra note 1. at 26 (reporting that Zimbabwe eamed over $\$ 13$ million from elephant products in 1980's. (wo-thurds from ivory). Some local communities have $\$ 1.6$ million (pre-ban prices) of slockpiled ivory ld.

82. Parks and Wild Life Act, No. 14 (1975); Alastair Bradstock. Communury Is Key to Consenution. Geographical MaG., Dec. 1990, at 17, 17.

83. Bradstock, supra note 82 , at 17.

84. Id.

85. BONNER, supra note 2, at 285. This is consistent with the common law doctnne of rattone solt. which dictates that possession of animals is vested in the owner of the land on which they are found. See Keeble v. Hickeringill, [1558-1774] All E.R. Rep. 286 (Q.B. 1707) (reprint co.), reprinted in JESSE DUKEMINIER \& JAMES E. KRIER, PROPERTY 31 (3d ed. 1993) (affirming property nght in animal "seduced" onto property owner's land). This doctrine contrasts with the United Stales" appranch. whereby wildlife is held in public trust by state governments for the benefit of the people. See Geer v. Connecucut. 161 U.S. 519 (1896). It also differs from the colonialist attitude that reserved wildlife for European elites. See Child. supra note 62 , at 60 .

86. BONNER, supra note 2, at 262-63. In 1989. the Zimbabwe Trust allocated $\$ 1.5$ million over five years to further the reestablishment of Nyaminyami's wildlife management program. CAMPFIRE is a significant part of this program. Id.

87. Id. at 253 .

88. Bradstock, supra note 82 , at 17.

89. Id.

90. Child, supra note 62 , at 61 .

91. Id.

92. See BONNER, supro note 2, at 268 (noting improved equipment and higher pay for game wardens) Each of 12 wards in Nyaminyami earned $\$ 3200$ from wildlife for 1989 . Rucciul, supra note 1 . at 34

93. See Child, supra note 62 , at 61 .

94. See Simmons \& Kreuter, supra note 61, at D3. 
principally on sport hunting, ${ }^{95}$ and has reduced its culling operations. ${ }^{96}$ Communities sell hunting permits ${ }^{97}$ that can earn between $\$ 12,000^{98}$ and $\$ 25,000 . .^{99}$ Part of this revenue is returned to the community, while part is dedicated to national wildlife protection..$^{100}$ Individuals who sustain crop damage are still compensated, ${ }^{101}$ and the meat from wildlife is sold at cost to local communities. ${ }^{102}$ Local populations continue to receive "cash dividends from the proceeds of wildlife management"103 that give them an incentive to preserve elephants.

Zimbabwe's philosophy is also manifest in its acceptance of purely private wildlife ownership. For example, the Save Conservancy reserve, created by ranchers who have collectively fenced in their property, provides a refuge for animals driven from drought-stricken parts of the country. ${ }^{104}$ The owners have set up antipoaching patrols and wildlife management programs, ${ }^{105}$ having found that wildlife can be a more lucrative use of land (even with the ban) than livestock. The arid, harsh land does not support cattle stocks particularly well, but wildlife flourishes more readily, ${ }^{106}$ allowing the ranchers to earn money from tourism, including photographic safaris, and trophy hunting. ${ }^{107}$ These earnings allow the ranchers to improve their antipoaching patrols and to receive more advanced scientific advice as to how many animals they may cull to preserve a sustainable population. ${ }^{108}$

Since the CITES ban on elephant products went into effect, the success of the program in Nyaminyami has declined. For example, fewer elephants were culled in 1990 than the regional management plan for that year deemed appropriate. ${ }^{109}$ Although sport hunting continues, ${ }^{110}$ the local warden estimated that the inability to sell the tusks and hides cost the district $\$ 20,000$

95. Child, supra note 62 , at 61 .

96. See Mary Cole, Zimbabwe To End Experiment in Conservation?, NEw SCIENTIST, June 12, 1993, at 8,8 .

97. Child, supra note 62, at 61; Simmons \& Kreuter, supra note 61, at D3.

98. Child, supra note 62 , at 61 .

99. Simmons \& Kreuter, supra note 61, at D3.

100. Child, supra note 62 , at 61 .

101. Bradstock, supra note 82 , at 17.

102. Id.

103. Id.

104. Mary Cole, Private Reserve for Zimbabwe's Thirsty Elephants, NEW SCIENTIST, July 25, 1992. at 10,10 .

105. Id.

106. One estimate suggests that tourism earns $\$ 50-100 /$ hectare annually, and hunting $\$ 10 /$ hectare, whereas cattle ranching can lose \$5/hectare. ADAMS \& MCSHANE, supra note 4, at 172.

107. Cole, supra note 104 , at 10 . There has been a recent move away from hunting and toward tourism, but culling may be necessary nonetheless. Id.

108. Id.

109. BONNER, supra note 2, at 271 (noting that 69 elephants could have been killed while sustaining the population, yet suggesting fewer than that were actually killed). Zimbabwe uses a computer simulation model to help determine which elephants to kill and what proportion of the population to cull. Ricciuti, supra note 1 , at 27 .

110. Bradstock, supra note 82, at 17. 
in the first eight months of the year."' This amount is equivalent to approximately $25 \%$ of the total income of the area. ${ }^{112}$ The warden estimated that Nyaminyami would have earned $\$ 125,000$ from the sale of ivory had the number of culls reached the number of elephants that the management determined could be killed. ${ }^{113}$ This amount is roughly equivalent to the total that the Nyaminyami district receives in foreign aid for nutrition and primary education programs. ${ }^{114}$ The effect of the CITES ban on elephant and ivory trade was to place a significant obstacle in the way of the achievement of Zimbabwe's preservation goal. The ban on ivory sales removed a vital source of funding, ${ }^{115}$ and consequently Zimbabwe's ability to afford protection for the animals declined.

Between the ban on ivory trade and internal political changes, the continuation of CAMPFIRE is unlikely. ${ }^{116}$ Both before and after the ban, however, Zimbabwe's general policy has been to allow its people to share the profits wildlife can earn as compensation for the headaches it can cause. The policies provide incentives to communities to protect their wildlife because perpetuation of the elephant population allows them to earn money from tourism, while culling (prior to the CITES ban) and trophy hunting allow them to earn profits from elephants.

South Africa, like Zimbabwe, actively manages its wildlife to maximize its usefulness to the local population. Kruger National Park, the centerpiece of the South African game park system, is amply fenced to keep poachers out and animals in, and its antipoaching patrols are fully effective. ${ }^{17}$ Like Zimbabwe's communities, the park profits from elephants. It pays for its operations through admissions fees and other tourist expenditures, and (prior to the CITES ban) through the sale of tusks and hides from culled elephants. Unlike Zimbabwe, ownership of wildlife is vested in the South African people through the government, rather than directly through local property rights.

Kruger has so successfully protected its elephants that park managers have culled elephants simply to ensure that the herds did not grow too large and decimate the vegetation. ${ }^{118}$ Prior to the trade ban, South Africa could profit from its success in preserving the species by using funds from sales of elephant parts to provide improvements in the habitat for elephants as well as

111. BONNER, supra note 2, at 271. Only those elephants that were damaging crops and could not be chased away were actually killed. See also Ricciuti, supro note 1, at 34 (")We like wildlife more than before, but not 100 percent. They still kill people when crops are in the field. We have tusks(.) " would benefit us more if we could sell them."' (quoting local resident)).

112. BONNER, supra note 2 , at 271 .

113. Id.

114. Id.

115. Cf. Bradstock, supra note 82, at 17 (claiming that although ivory sales "made up just a small proportion of the income from the safari hunt ... (they) still made a significant difference").

116. See Cole, supra note 96 , at 8 .

117. Perlez, supra note 40 , at $\mathrm{C4}$.

118. Id. 
other wildlife. The government also used these funds to improve the park for tourists. Now, however, the country may profit only from tourist revenues.

The overriding aim of the southern African management programs is consistent with the goals of a CITES Appendix II animal listing: preservation of the species through close attention to its condition and habitat. Appendix II prohibits trade only when such trade is "incompatible with [the species'] survival." 119 Zimbabwe and South Africa have made good-faith efforts to engage only in trade that does not interfere with their recognized responsibility to maintain elephant populations at a sustainable level, ${ }^{120}$ and both countries have demonstrated that trade can, in fact, actually support preservation of the species. The number of elephants culled each year is determined by reasonable scientific estimates of what the habitat can support, rather than a shortsighted, profit-oriented approach.

\section{B. Protective Strategies}

Kenya's management plan bans all hunting and killing of elephants. ${ }^{121}$ Since 1978, Kenya has sought to protect all elephants, as well as other wildlife, from poachers. ${ }^{122}$ The nation has chosen to focus on tourism as a means of earning revenue from the elephant-a reflection of an ideology that holds that people should profit from wildlife through its viewing value only. ${ }^{123}$ In 1989, the President of Kenya dramatized the country's commitment to this belief by setting fire to a pile of confiscated elephant tusks worth about $\$ 3$ million, rather than selling the ivory to provide additional protection funds. ${ }^{124}$

Kenya's antipoaching efforts in the 1980's were unsuccessful. Because Kenya had limited funds for conservation, the decline of the country's elephant population continued throughout the decade. The nation spent only a fraction

119. CITES, supra note 7, art. II, para. 2, cl. a, 27 U.S.T. at 1092, 993 U.N.T.S. at 245.

120. A plausible argument can be made that some legal sales of ivory help support the survival of the elephant elsewhere. A legal supply of ivory reduces pressure on other supplies, so that poaching elsewhere should diminish. Thus, legal ivory may undercut the market for poached ivory, given the additional costs of obtaining ivory through poaching. See Mary Cole, Hologram To Herald Resumption of Ivory Trade, NEw SCIENTIST, Dec. 12, 1992, at 7, 7 ("'The illegal trade has a monopoly on the market .... If legal trade was opened between, say, SACIM and Japan there would be no middle men and the cost of the end product would be lower, which would make the illegal trade uneconomic." (quoting Rob Monro of the Zimbabwe Trust)); cf. Killing a Giant for Its Teeth, supra note 59, at 8 (noting killing of hippopotamuses for their ivory teeth as substitute for elephant ivory).

121. See supra notes 74-75; see also Isabel Wolff, Elephant Man, GEOGRAPHICAL MAO., Sept. 1991. at 40,41 .

122. In 1977, Kenya banned sport hunting. See supra note 74 . The following year, Kenya banned all trade in wildlife products. BONNER, supra note 2, at 216; see supra note 75.

123. Simmons \& Kreuter, supra note 61, at D3; see Iain-Douglas Hamilton, You Can Help Elephants, WILDLIFE CONSERVATION, Mar.-Apr. 1993, at 74, 74 (reporting estimated income of $\$ 25$ million per year from elephant tourism).

124. Simmons \& Kreuter, supra note 61, at D3. 
of what was estimated as necessary to protect its elephant population. ${ }^{125}$ Ranger salaries were very low, leaving personnel prone to poachers' bribes. $^{126}$ A 1990 Kenyan government report detailed the underlying problem: corruption. ${ }^{127}$ High-level Kenyan officials were involved in the corruption, making its elimination substantially more difficult. ${ }^{128}$ This corruption affected Kenya's one legitimate source of revenue from the elephant: park gate receipts. ${ }^{129}$ Entrance fees were lining the pockets of government workers, rather than being returned to pay for improvements to the parks or to the surrounding area. ${ }^{130}$

Until 1989, Kenya compensated farmers who lost crops to wildlife damage, thereby helping to reconcile the conflict between elephant preservation and human population needs. The farmlands from which elephants were feeding frequently were the poorest in Kenya, ${ }^{131}$ thus making compensation even more necessary. In 1989, however, Kenya repealed the law providing compensation to farmers because the growing number of claims substantially exceeded the budgeted amount. ${ }^{132}$ Fraud, consisting primarily of claims for unfarmed land, contributed to the demise of the program. ${ }^{133}$ Kenya's policy of protecting elephants without profiting from them has thus led to two problems: an inability to fund adequately its antipoaching efforts, and the exclusion of human needs from the solution.

Kenya's protection program has improved over the last three years. A reorganization of its wildlife service has helped reduce corruption. ${ }^{13 *}$ It has also instituted a stricter shoot-to-kill policy toward poachers. ${ }^{135}$ Furthermore, Kenya hopes to obtain $\$ 200$ million in funding from other nations to improve elephant protection and tourist facilities. ${ }^{136}$ These recent changes suggest that Kenya's strict protective approach may work, if properly organized and funded. Whether its success can be sustained over longer periods, especially if outside funding does not materialize, remains to be seen.

The Kenyan approach is essentially the same as that adopted by CITES for Appendix I species. The rule is that no elephant products may be sold because

125. BONNER, supra note 2, at 93 (reporing expenditures of $510 / \mathrm{km}^{2}$, while suggesting that $\$ 200-400 / \mathrm{km}^{2}$ is necessary).

126. See id; id. at 134 (noting that "rangers . . poached out of need, out of desperation." sometimes to help their children attend school).

127. Id at 134-35.

128. Id. at 135 .

129. Id.

130. See id. at 136.

131. See id. at 214 .

132. Id.

133. Id. Note, however, that claims may now be compensaled with proviston of schools and health centers. Waithaka, supra note 57, at 63 . Such remuneration is, however. considered inadequate, partly because other areas, undamaged by elephants, receive these goods too. $l d$.

134. See Wolff, supra note 121 , at 40 .

135. Id. at 41.

136. See id. at 42. 
any trade is believed to be per se detrimental to the species. There is no acknowledgment that limited trade may be consistent with the survival of the species, as is true of Appendix II animals. It is a bright-line rule: Trade is detrimental to the species and therefore banned.

\section{Results of the Strategies}

Elephant populations in Kenya have declined substantially during the 1980 's. The population dropped during the decade from an estimated 65,000 to approximately $19,000 .{ }^{137}$ Other countries in eastern and central Africa, using policies resembling that used in Kenya, have had similar declines. ${ }^{138}$ In contrast, Zimbabwe's elephant population has grown during the same period from 30,000 to at least $43,000 .{ }^{139}$ Botswana, using a management scheme like Zimbabwe's, has seen its elephant population double to 56,000 over the last decade. ${ }^{140}$ Elephant populations have been increasing 5\% annually in recent years in the countries using this type of active management approach. ${ }^{141}$ The southern African active management strategy thus appears to protect the elephant species more successfully than Kenya's protective strategy.

Because of the profitability of wildlife and the success of CAMPFIRE, the amount of land available for wildlife in Zimbabwe increased threefold between 1988 and $1993 .{ }^{142}$ In one area people abandoned their homes and created a more centralized settlement to allow more room for wildlife to flourish. ${ }^{143}$ Another community dug waterholes and provided food to maintain the elephant population during a drought. ${ }^{144}$ Thus, Zimbabwe's program has helped to reconcile human settlement with animal needs for habitat preservation in a way that redounds to wildlife's benefit. Kenya's program has not enjoyed nearly the same success.

137. Simmons \& Kreuter, supra note 61 , at D3 (reporting decline from 65,000 to 19,000 between 1979 and 1989); see also U.N. ENVTL. PROGRAMME, 1991/92 ENVIRONMENTAL DATA REPORT 207 (3d ed. 1992) [hereinafter UNEP REPORT] (16,000 in 1989); Ricciuti, supra note 1, at 17 (reporting 167,000 in 1973 and 16,000 in 1989); Wolff, supra note 121 , at 40 (reporting decline from 60,000 in early 1980's to less than 17,000 in 1989). Estimates of the Kenyan elephant population have recently increased to 26,000, but the increase may reflect better methods of elephant counting, rather than an actual increase in population. See id.

138. Simmons \& Kreuter, supra note 61 , at D3.

139. Id. (reporting increase from 30,000 to 43,000 between 1979 and 1989); see also UNEP REPORT, supra note 137, at 207 (52,000 in 1989); Ricciuti, supra note 1, at 17 (32,000 in 1960, 52,000 in 1989, 70,000 in 1993).

140. BONNER, supra note 2, at 91; see also UNEP REPORT, supra note 137, at 207 (68,000 in 1989).

141. Simmons \& Kreuter, supra note 61, at D3; see Ricciuti, supra note 1, at 26.

142. Cole, supra note 96, at 8; cf. Child, supra note 62 , at 60 ("'T]he real breakthrough is that the rural poor are also setting aside land for wild animals.").

143. Child, supra note 62 , at 61 .

144. Id. 
Zimbabwe's management strategy has also addressed the problem of insufficient funding for elephant protection more successfully than has Kenya's protective strategy. Zimbabwe's program helped replenish the government's coffers through the sale of ivory and other elephant products. Kenya's refusal to sell ivory meant that it did not benefit from these potential revenues. Thus, Zimbabwe's elephants generated more of their own protection money than did Kenya's because Zimbabwe sold ivory. These results suggest that Zimbabwe's active management program is the better method of preserving elephants.

\section{PROPERTY RightS, TRADE BANS, AND ElEPHANTS}

Theoretical literature on property rights and the tragedy of the commons helps to explain why active management programs are likely to be more effective than protective programs in preserving the elephant species. A lack of defined property rights has long been recognized to lead to overuse of a resource. $^{145}$ If no one person or entity has control of a resource, then individuals acting rationally will overconsume from the commons. The core problem is that any person who tries to conserve a resource by husbanding it today will see a competitor take the resource instead, leaving the conservationist with nothing tomorrow. ${ }^{146}$

\section{A. Commons Problems}

The commons examples most pertinent to the elephant come from natural resource economics. The commons problem of underground oil pools is well documented. ${ }^{147}$ Common law applies the familiar rule of capture for migratory and fugitive resources to an oil field: Whoever pumps the oil first owns it. ${ }^{148}$ Ownership rights attach only upon extraction, not discovery. ${ }^{149}$ This common law rule typically leads each firm that owns land over an oil field to drill and drain the pool as quickly as possible. Each firm tends to overcapitalize in order to pump more quickly, and therefore they collectively dissipate any potential excess profits or rents. ${ }^{150}$ Overly rapid extraction,

145. See Garrett Hardin. The Tragedy of the Commons, 162 ScIENcE 1243 (1968)

146. See Anthony Scoth. The Fishen: The Objecuves of Sole Ownership. 63 J. POL Ecox. 116. 116 (1955) ("No one will take the trouble to husband and manntain a resource unless he has some reasonable certainty of receiving some portion of the product of his management . . . .).

147. See, e.g., Gary D. Libecap \& Steven N. Wiggins, Contractual Responses to the Common Pool Prorationing of Crude Oil Production. 74 AM. ECON. REV. 87 (1984).

148. See, e.g., Westmoreland \& Cambria Natural Gas Co. v. De Witt. 18 A. 724. 725 (Pa. 1889) ("[Subsurface oil, gas, and water] belong to the owner of the land, and are par of 11 , so long as they are on or in it, and are subject to his control: but when they escape . . . the title of the former owner is gone."); cf. Pierson v. Post, 3 Cai. R. 175. 175 (N.Y. Sup. Ct. 1805) (applying rule of capture to the "'noxious beast[] called a fox"').

149. Libecap \& Wiggins, supra note 147 , at 88.

150. Id. 
furthermore, reduces the total amount of oil a pool yields. ${ }^{151}$ Therefore it is advantageous to have a single extractor, or at least coordinated extraction, in order to encourage an optimal level of capitalization and to maximize the total quantity of oil withdrawn. The common law rule for oil, however, creates incentives to exceed the optimal removal rate in the race to capture the oil.

Marine life provides even richer examples of commons problems. Surf clams have been overexploited because of unrestrained access to clam flats. ${ }^{152}$ Surf clams are a typical common resource: Too many people harvest the clams; clammers invest too much in equipment in order to increase their share of the catch; and the clams are harvested before the optimal, fully grown time. ${ }^{153}$ Solutions to commons tragedies must address these three problems.

Townsend and Wilson summarize the economic analysis of the commons problem by examining the fishery. ${ }^{154}$ They show that in an unregulated fishery (generalizable to any open-access commons), entry of new fishermen will continue as long as economic returns exceed those that could be earned if the fishermen were employed in other occupations. ${ }^{155}$ At this level of participation, total revenue and total cost are equal, as entry has dissipated all profits. Unfortunately, this level of fishing is not sustainable: The stock of fish grows ever smaller. ${ }^{156}$ Profits and fish stocks may be sustained, however, if the fishery is properly managed and access restricted. Maximum profits obtain when total revenue less total cost is at its greatest. ${ }^{157}$ This point is also where marginal revenue and marginal cost are equal, the classic profit-maximizing position. ${ }^{158}$ More important, this fishing level is lower than that at which fish stocks are stable, ${ }^{159}$ meaning that the properly managed commons will have an even greater stock of fish than it would if the maximum sustainable number were withdrawn. ${ }^{160}$

The problem of the elephant fits well into the commons paradigm. If no person owns the elephant, but the elephant itself has value, rational actors each will seek to take the elephant before someone else does. An elephant left alive in the commons is valued by none, ${ }^{161}$ and therefore is taken as quickly as possible. Just as people will race to take surf clams or fish, people will seek

151. See id. at 89.

152. Franz T. Litz, Harnessing Market Forces in Natural Resources Management: Lessons from the Surf Clam Fishery, 21 B.C. ENVTL. AFF. L. REV. 335, 345 (1994).

153. Id. at 338.

154. Ralph Townsend \& James A. Wilson, An Economic View of the Tragedy of the Commons, in TuB QUESTION OF THE COMMONS 311 (Bonnie J. McCay \& James M. Acheson eds., 1987).

155. Id. at 316.

156. See id. at 315-17 (noting total revenue equals total cost at effort level consistent with decreasing fish stocks).

157. See id. at 317.

158. See, e.g., Paul SAmuelson \& William Nordhaus, EConomics 172-73 (14th ed. 1992).

159. Townsend \& Wilson, supra note 154 , at 317 .

160. Id.

161. This analysis excludes, for the moment, tourism value derived from live elephants and focuscs on individual incentives to capture elephants for ivory. 
to capture the elephants before someone else does because the expected future value of the resource is zero. There is no incentive to invest in the future of the resource. Such a bias toward the present leads to the resource's depletion.

Although regions may reap tourism revenues from the elephant, an individual cannot realize an elephant's full value until the elephant is dead: Capturing the value of the resource requires slaughtering the elephant. ${ }^{162}$ Just as no one is able to capture for herself the value of clams left on tidal flats, a hunter profits little, either from ivory or from tourism, when she leaves an elephant in the wild. Under a common propeny regime, one must kill an elephant and possess it in order to remove it from the commons and make it one's own. ${ }^{163}$ Elephants are consumed more quickly than is optimal from a societal standpoint because no one has an incentive to conserve elephants. In effect, an elephant left in the wild has a value of zero. All the incentives motivate hunters to kill elephants as quickly as possible.

\section{B. Commons Solutions}

Typical solutions to commons problems involve controls on the supply of or demand for the resource. Reductions in demand diminish the incentives to take the resource. Trade bans are intended to reduce overall demand, and thus to reduce the number of elephants that are killed. Demand can also be reduced through moral suasion. If everyone is convinced that ivory is useless (or has substitutes ${ }^{164}$ ), or is morally wrong to own, demand will drop, and fewer elephants will be killed. The trick is to convince people of the evil ivory production entails. This method, in theory, works as well as reducing demand through market elimination. ${ }^{165}$

These methods do not always successfully reduce demand, ${ }^{160}$ however, and markets usually develop to meet any residual demand. ${ }^{167}$ There will

162. One study has noted that to sell ivory one must kill its "factory." WOUTER VAN DIEREN \& MARIUS G.W. HUMMELINCK, NATURE'S PRICE: THE ECONOMICS OF MOTIER EARTI 137 (1979); see also supra note 9.

163. The country may earn income from tourism. but it is difficult (if not impossible) for an individual to capture that value. If a "poacher" could take the animal to her own 200 and charge admission, she could capture the tourist value. If the elephant is a common resource, however, no one can appropnate this tounst value for herself.

164. For example, new plastic-making techniques are being developed to make pasno keys with a feel indistinguishable from that of ivory piano keys. See Malcolm W. Browne. With lvory in Short Supply. Pianists Tickle the Polymers, N.Y. TiMES, May 23. 1993. at Cl. However. the ivory demands of piano companies-two tusks per year for a large company-hardly affect overall demand $l d$.

165. See Carol M. Rose. Rethinking Environmental Controls: Management Strategtes for Common Resources, 1991 DUKE L.J. 1, 31-32 (suggesting moral suasion can sometimes be effectuve at lower cost than other methods). The examples Rose provides generally involve face-lo-face contact between people with confiicting interests, a situation not present in the elephani's case.

166. Bradstock, supra note 8 , at 14; see also supra note 8 and accompanying text.

167. See supra notes 5-8 and accompanying text for evidence of black markets in ivory developing to circumvent intemational laws. See also Whose Elephanis Are They Aniway?. TuE ECovosisT. Nov. 5. 1994 , at 46, 46 (reporting 35 tons of black market ivory seized in last (wo years) 
always be some people who enjoy having something that very few others have, perhaps because it is rare or expensive. ${ }^{168}$ Diverse cultural attitudes make a comprehensive elimination of ivory demand nearly impossible. ${ }^{169}$ As long as there remains a demand for ivory, there will remain incentives for someone to kill elephants to supply that demand.

Other possible solutions to commons problems involve controls on supply. In theory, a prohibition on ivory trade makes it more difficult for a person who kills an elephant to sell the ivory. This, in turn, will make a poacher less likely to incur the costs of obtaining the ivory. ${ }^{170}$ Making a market illegal changes incentives. Providers of the illegal product incur the costs of evading law enforcement and may incur costs from confiscation of the product as well as penalties. These costs increase the overall cost of supplying the product, most likely increasing price and reducing the quantity traded. ${ }^{171}$ Thus, diminishing the rewards of ivory acquisition through a ban should decrease such acquisitions, thereby sparing the elephant the blast from the poacher's assault rifle. Markets for illegal products, however, have ways of developing to meet demand, ${ }^{172}$ so eliminating legal trade may be a fruitless attempt to eradicate trade in elephant tusks completely.

There are several typical methods of controlling supply to reduce the pressure on a common resource. Carol Rose identifies four general strategies for managing common resources: doing nothing; prohibiting new entrants from taking; prescribing methods by which the resource may be taken; and defining property rights. ${ }^{173}$ Doing nothing to manage a common resource is what led to the need for action: Because poachers have been allowed to kill elephants wantonly, the elephant population has been decimated. Some affirmative

168. See supra note 8.

169. See FAVRE, supra note 8, at 123; cf. Michael Tennesen, Poaching. Ancient Traditions and the Law, AuduBoN, July-Aug. 1991, at 90, 92 (noting frequent inconsistencies between Western values and other cultural traditions).

170. There are costs to killing elephants, including search costs, equipment costs, and processing costs.

171. There is a downside to making the market illegal. Two notable problems are that it limits opportunities to monitor the market, see SARAH FITZGERALD, INTERNATIONAL WILDLIFE TRADE: WHOSB BUSINESS IS IT? 109 (1989) (noting trade ban on rhinoceros horn makes "tracking market routes difficult"), and that other forms of regulation are made impossible, $c f$. STEVEN B. DUKE \& ALBERT C. GROSS, AMERICA's LONGEST WAR: RETHINKING OUR TRAGIC CRUSADE AGAINST DRUGS (1993) 194-97 (arguing illegality of drugs leaves their safety completely unregulated). The inability to monitor is crucial for the purpose of ascertaining which countries are managing their elephant populations well. An inability to regulate the market means that there is no possibility of putting other constraints on the market. For example, a complete ban precludes the possibility of either a quota system or a taxation scheme. Taxing ivory might allow revenues to be returned to countries to help preserve elephants. Cf. Rose, supra note 165 , at 36 (arguing that pollution taxes can be used for environmental improvements).

172. See, e.g., Richard M. Epstein, The Moral and Practical Dilemmas of an Underground Economy, 103 YALE L.J. 2157, 2164-76 (1994). Despite American efforts to eliminate the illicit drug trade, drugs are still available. See, e.g., DUKE \& GROSS, supra note 171; The Wages of Prohibition, supra note 55. A ban on rhinoceros horn trade has failed to stem the flow of horn to demanding countries. See infra part V.

173. See Rose, supra note 165, at 9-10. Rose suggests that prescribing the method of taking is akin to command-and-control regulations, see id. at 10 , which allow takings only in a prescribed manner. Id. at 19. 
strategy is necessary to preserve a sustainable number of elephants. Preventing access of new hunters to the commons would be similarly ineffective; additional restrictions, such as a limit on the total number taken, would still be necessary. ${ }^{174}$ Prescribing specific technologies for taking from the commons would be nearly impossible. Game wardens have found it difficult to identify poachers, and it would be no easier for them to certify whether a hunter was using the proper rifle. The remaining solution under Rose's model is a system of property rights.

Assignment of some form of property rights has often been the preferred solution to commons problems. Each of the problems noted in Section A of Part III has been ameliorated through an allocation of "taking rights." A common solution to the problem of the shared oil field is unitization. This strategy gives the extraction rights to one company and then allocates the costs and revenues to each of the owners of the oil field. ${ }^{175}$ The alternative solution is to prorate the oil by assigning quotas and allowing oil withdrawal to be controlled by central agreement among the owners. ${ }^{176}$ Such solutions essentially vest a right in the oil prior to extraction, thereby eliminating the race to extract the oil that would have led to overcapitalization and wasted resources.

Long-overfished fisheries have recently begun to implement quota systems to restrict fishing to sustainable levels. New Zealand has already created a system of transferable quotas for its fishermen, ${ }^{177}$ and the United States has been contemplating implementation of such a program. ${ }^{178}$ An entitlement to a certain amount of fish reduces destructive competition because it eliminates the incentive to race to capture the resource. The quota "is, in effect, reserved for that fisherman." 179 A quota allows fishermen to pursue a least-cost strategy ${ }^{180}$ for collecting their fish, unencumbered by the seasonal, gear, size, and area restrictions previously employed to slow the depletion of the resource. $^{181}$ The plan eliminates the inefficient restrictions imposed on fishermen to slow the taking of fish, and replaces them with a simple quota.

The surf clam problem has been ameliorated by the implementation of "quasi-property rights." 182 This strategy involves first establishing a total quota on the number of harvestable clams. Next, the quota is divided and

174. See WILSON \& AYERST, supra note 8. at 150 (noting that colonies granted licenses to limited number of people for certain number of elephants each year).

175. Libecap \& Wiggins, supra note 147, at 89.

176. Id. at 90 .

177. See Lit, supra note 152 , at 349 nn.149. 353.

178. See Peter Passell, U.S. Giving Certain Boat Owners Excluswe Rights To Fish off Coust. N.Y TIMES, Apr. 22, 1991, at A1.

179. William J. Milliken, Individual Transferable Fishung Quotas and Anutrust Luw, I OCEAN \& COASTAL L.J. 35, 39 (1994).

180. Id. at $39-40$.

181. Id. at 37.

182. Litz, supra note 152 , at 341 . 
allocated to the various clammers according to a formula. ${ }^{183} \mathrm{~A}$ tagging and registration system ensures that the clammer was entitled to catch the clams she brings to dock. ${ }^{184}$ The quotas provide incentives for fishermen to maximize the value of their harvest by taking only the most valuable clams, and thus the harvesting occurs at the "socially optimal age." 185 Stable stocks of clams and reductions in the over-capitalization of the industry provide early evidence of the success of the system. ${ }^{186}$ The most important part of this plan is the setting of the overall quota: It is set so that clams are harvested at a sustainable level, and therefore eliminates the problem of resource depletion. $^{187}$

Another fruitful example of property-rights-based solutions to commons problems comes from the lobster industry. ${ }^{188}$ In Maine, two systems of lobster allocation prevail. Both involve membership in a "harbor gang."189 The critical difference is how these gangs defend their areas. Gang areas are either nucleated, with rights strongest near the gang's own harbor; or perimeter-defended, with the gang holding exclusive rights to lobster within a certain area. ${ }^{190}$ Rights in a nucleated area are not necessarily exclusive. Nucleated areas may overlap, and on the margins members of different gangs may both set lobster traps. ${ }^{191}$ Perimeter-defended areas, in contrast, are lobstered exclusively by their gangs. ${ }^{192}$ The property right, therefore, is more exclusive in the perimeter-defended areas.

A comparison of the two territorial lobster allocation methods reveals the advantages of exclusivity in a private property regime. In perimeter-defended areas, capital investment is lower: Fewer boats per square mile are used. ${ }^{193}$ Likewise, lobstermen need to exert less effort for an equal catch. ${ }^{194}$ The lobsters caught are larger and hence more valuable. ${ }^{195}$ Thus the perimeterdefended system requires less investment and labor but yields a higher return than the nucleated system.

183. Id. at $341-43$. These allocations may subsequently be bought and sold. Id. at 357 .

184. Id. at $350-51$.

185. $l d$. at $344-45$.

186. Id. at 359 .

187. Id. at 348. A similar scheme of allocating oyster beds to specific oyster fishers was successful for many of the same reasons. See Richard J. Agnello \& Lawrence P. Donnelley. Property Rights and Efficiency in the Oyster Industry, 18 J.L. \& ECON. 521, 532-33 (1975).

188. James M. Acheson, The Lobster Fiefs Revisited: Economic and Ecological Effects of Territoriality in the Maine Lobster Industry, in THE QUESTION OF THE COMMONS, supra note 154, at 37.

189. Id. at 40 .

190. Id. at $40-45$.

191. See id. at 42 .

192. See id. There are occasional violations of both kinds of areas. Such incursions often lead to the destruction of the intruder's lobster traps and gear. $I d$. at 41 .

193. Id. at 49

194. Id. at 55.

195. Id. at 55-57. 
These solutions to commons problems are similar in two respects. First, claims to resources are spread over time. That is, a person is guaranteed a specified claim on the resource now and in the future. ${ }^{106}$ This overcomes the problem of the surf clam, because now a person can leave a clam on the flat and be assured that someone else will not take it. The resource's future value to the harvester is no longer zero. The second commonality is that takers are identifiable. The people clamming know who else is entitled to how many clams, and are able to enforce that limitation. Thus the right is not only extended over time but is also defensible.

\section{The Programs Compared: Management Versus Protection}

Southern African governments have attempted to enlist the virtues of property regimes in their policies. Zimbabwean wildlife policy creates a property right in wildlife. Rather than waiting until the elephant has been killed to recognize possession, the government has recognized that a property interest exists while the elephant is still alive. Thus a person who kills an elephant after she has a vested property right is no longer taking it from the commons, but rather is killing what is already hers. Because the property right protects her ability to profit from the elephant in the future, she has a greater incentive to protect it than the person who must kill the elephant immediately in order to profit.

Zimbabwe identifies the community as the owner of the elephants. ${ }^{197}$ Because the community is entitled to exclude others from taking the elephants, it will be able to capture the elephants' value now or in the future. The property right allows the "owners" to determine which elephants it is advantageous to kill for profit and which elephants they should preserve for

196. As long as the user of a fishery is sure that he will have propery rights over the fishery for a series of periods in the future. he can plan the use of the fishery in such a way as to maximize the present value (future net returns discounted to the present) of his enterprise. From the social point of view it can be sard that he will bring about the "best" use of the fishery ....

Scoth, supra note 146 , at 122.

This analysis assumes that owners of entitlements have confidence that the resource will not be depleted despite the presence of a property system. If people believe that elephanis will disappear soon (because of poachers, say) then the owners will want to take their share as quickly as possible, before someone else does. People generally have an incentive not to respect property nghts untl everyone abides by the property regime. For a discussion of this collective organization problem, see Carol M. Rose, Property as Stonytelling: Perspectives from Game Theon, Narraine Theon: Femunist Theory. 2 YALE J.L. \& HUMAN. 37, 48-53 (1990) (arguing that cooperation of otherwise individualistic actors is necessary to create property-rights-based protections). One potential threat to secure properyy interesis in Zimbabue is the government's current land redistribution policy. See Neil Henry. Fam-Takeover Plan Rotls Zimbabwe. WASH. POST, Feb. 20, 1991, at A6 (reporting Zimbabwe's plan to setze commerctal farms for resettlement by poor families). Such uncertainty will cause people to value future property nghts less and possibly accelerate killing of elephants.

197. See supra part II.A. 
breeding or other purposes. ${ }^{198}$ Either way, the community shares the proceeds. The community loses revenue only if it lets poachers steal the elephants.

Community members can easily identify "owners" of the elephants because anyone not a member of the community does not have an elephant entitlement. The profit motive provides a strong incentive to prevent poaching, which is essentially stealing from the community. In these communities, as in the harbor gangs, no single person has rights to an elephant. A close-knit community controls access to the resource. ${ }^{199}$ This effectively creates central ownership and control. Because the communities generally share the wealth, there is little incentive or opportunity for individual appropriation. ${ }^{200}$

The local management programs create incentives to preserve the elephant population at a sustainable level. The Zimbabwean government provides scientific advice on the appropriate number of elephant culls and supervises to ensure that culls are not excessive. Zimbabwe focuses on guaranteeing the survival of a certain and substantial number of elephants. ${ }^{201}$ By sharing profits from elephants with communities now and establishing community rights to them in the future, Zimbabwe has reduced incentives to kill elephants.

South Africa, like Zimbabwe, has chosen to manage wildlife actively and to use the proceeds to increase wildlife protection. ${ }^{202}$ Kruger National Park funds itself with revenues from admissions fees and from the proceeds of culling. The park's ability to profit directly from wildlife gives it an incentive to manage its wildlife carefully. South Africa's approach also effectively balances human and wildlife needs. Within the park, South Africa ensures that humans cannot encroach upon wildlife, ${ }^{203}$ and the exclusion of human settlement means that no local populations are threatened by the wildlife. ${ }^{204}$

South Africa and Zimbabwe recognize the competition between elephants and humans for land as well as the demands for the use of wildlife. Zimbabwe

198. If the elephant's "owner" has a future interest in the elephant, then that owner will consider not just the elephant's ivory, but also its ability to produce more elephants. In the extreme, farming of elephants solely for ivory and hides could occur. Assuming private ownership, only moral considerations would preclude such a system. There is debate as to the optimal harvesting time for an elephant's tusks. Tusks grow each year at an approximately constant rate, HARLAND, supra note 8, at 21 , and thus are their largest upon the elephant's death, Glennon, supra note 2, at 9.

199. See Child, supra note 62 , at 61 ("The [community management] process is democratic, and the opportunity for corruption is minimal because each member of the community is aware of who is responsible for which monies.").

200. Id. "When an animal is shot or photographed, the fees are put on the table as cash and the community debates how to use it.").

201. The theory, as described by Zimbabwe's Rowan Martin, Director of Department of Parks and Wild Life Management, is to use the available funds to protect as much wildlife as possible and to leave the remaining wildlife to others. ADAMS \& MCSHANE, supra note 4, at 171. Funding for wildlife protection could be increased if the ivory from culling could be sold.

202. See Perlez, supra note 40 , at $C 4$ (calling Kruger National Park "highly managed animal kingdom").

203. Id.

204. The park is amply fenced to keep animals in and poachers out. See id. 
relies upon a system of local management and property rights, while South Africa has implemented effective centralized park management. Each country has approached wildlife management from a similar perspective: They both realize that people are willing to pay to benefit from wildlife. By allowing groups in a position to control the resource to trade and to capture the profits, South Africa and Zimbabwe have provided incentives to maintain wildlife populations as well as to balance efficiently the clashing needs of wildlife and people.

Kenya, in contrast to Zimbabwe and South Africa, has decided not to allow its people to share in profits from wildlife, ${ }^{205}$ as local populations may not profit from culling or hunting and generally receive very little of the tourist revenue. ${ }^{206}$ Those most affected by the elephant's destructive capacity have few incentives to help keep the elephant alive. Furthermore, because trade in wildlife is prohibited in Kenya, there is no source of funding, other than direct government expenditures, to improve elephant protection. Kenya recognizes this fact, but is ideologically opposed to the culling of elephants to derive revenue. ${ }^{207}$

\section{Property Rights, Profits, and Protection}

Rose posits that of the four regulatory mechanisms she describes, there is no best solution for all occasions. ${ }^{208}$ As pressure on the resource increases, a more restrictive strategy will be more effective. The optimal regime is determined by comparing costs across these four possibilities. Rose shows that a property rights regime is preferable to a command-and-control regime once the cost of the latter type of policy becomes excessive. ${ }^{309}$

CITES, like other command-and-control policies, imposes enforcement costs on those trying to protect the elephant. ${ }^{210}$ In Kenya, all citizens bear a

205. In some sense this is a distributional issue. Kenya has allocated the property nght in wildlife resources to its government. The government has outlawed all culling and determined that only the central government may earn money from tourism revenue. In a truly democratue nation with efficient administration and enforcement, this allocative choice would matter little. Individuals would "own" a share of the elephant resources, held in trust by the government, and would benefit from the profits. They would also be able to influence the govemment's trade policies.

206. See BONNER, supra note 2, at 136 (reporting little of tournst revenue in Kenya is returned to communities in form of better services and infrastructure).

207. The principles underlying Kenya's position have been questioned. Compare Leakey, supra note 59 , at 59 (noting that Leakey, Director of Kenya Wildlife Service, objects to culling on moral and practical grounds) with BONNER, supra note 2, at 243 (noting that Leakey tacilly acknowledges potenual substantua! value of allowing hunting).

208. See Rose, supra note 165 , at 8-12, 37.

209. See id. at 24.

210. Command-and-control policies restrict methods of taking. See supra note 173. CITES simply restricts the possible methods to none: One cannot take the resource at all. CITES increases the cost of taking because one must run the risk of being caught with illegal goods or being killed by an antupouching patrol. Raising taking costs reduces the quantity taken, but antiporching patrols have not sufficiently raused the cost of ivory to sustain elephant populations. 
portion of these enforcement costs. In southern Africa, owners incur the costs because they must protect their elephants to maintain their property rights. ${ }^{211}$ Because southern African strategies have better-defined property rights, they encourage owners to reinvest funds earned from elephants back into environmental protection. ${ }^{212}$ In Zimbabwe, the costs of protection are recouped through profits from trade. One who maintains a herd is rewarded with additional valuable elephants.

Zimbabwe and Kenya illustrate the lessons learned from the various commons problems. The typical outcome prior to property rights is an overuse of the resource: The commons becomes depleted. Once a form of property rights is instituted, owners know that they have a right to profit from the resource in the future, and they become more interested in conserving. They take less in the present because they know the resource will be there for them in the future. So too with elephants: The right to profits in the future encourages conservation in the present.

The effect of listing the elephant on CITES Appendix I is to eliminate the ability to profit from managed culling. From the individual's and community's perspectives, this is tantamount to returning the species to the global commons where one cannot profit by husbanding a resource. Because individuals will expect to receive few future profits from the elephant, the incentive to take from the commons still exists, diminished only by the additional costs imposed on poachers by enhanced enforcement of the ban. And enhanced enforcement may be unaffordable, given the loss of funds previously earned from elephant trade.

211. Kenya's total ban on the ivory trade may be viewed as an allocation of the property right to the government, which in turn denies citizens the right to kill elephants. The two schemes, then, differ in efficacy and management costs. Involving local populations in the patrols and giving them incentives to work for elephant preservation will likely reduce costs. This is intuitively plausible because local populations will not need to be paid if they are compensated for their efforts by appropriate incentives.

Dean Lueck notes that wildlife trade restrictions are often chosen as a response to the higher cost of property rights enforcement, but that as property rights become stronger and better enforced, trade can more safely be permitted. See Dean Lueck, The Economic Nature of Wildlife Law, 18 J. LEGAL STUD. 291, 319 (1989). This has two implications for the elephant. First, a ban on trading (perhaps not universal, see infra text accompanying notes 250-55) may be useful as a transitional remedy until property rights are better defined and stabilized. If Kenya can develop a system like Zimbabwe's (with modifications to address local needs) then trade might be resumed. Second, where property rights have been well defined, open trade may be possible without the problems encountered in a system with ill- or under-defined property rights.

This explanation is insufficient to distinguish South Africa from Kenya, as both countries employ park wardens to defend elephants from poachers. Wardens have an incentive to take bribes and to allow poaching. This Note suggests in Part IV that corruption is less prevalent in South Africa than in Kenya because democratic processes are more likely to provide incentives to prevent such corruption.

212. Property rights in elephants allow the value of an elephant to accrue to the owner, and thus create incentives and resources to protect the entire species. Cf. FAVRE, supra note 8, at 123 ("The net result lof a ban] would be that the illegal takers of elephants would receive all the profits while the protectors of elephants would receive no economic benefit."); Rose, supra note 165 , at 36 (suggesting that sale of air pollution entitlements can raise money to enforce environmental regulations). 


\section{Elephants as a Corruption Problem}

The Zimbabwean property rights system allows individuals to profit from careful conservation of the elephant, thereby aligning individual incentives with preservation of the species. Local property rights cannot, however, explain the success of the South African system. Both South Africa and Kenya rely on parks and wildlife agencies, rather than on the community and local property rights, to protect their elephants. Although their policies appear similar, South Africa has enjoyed great success in protecting its elephants while Kenya has not. Kenya's program has been burdened by significant corruption in the operation of its protection programs and antipoaching patrols, ${ }^{213}$ a problem southern African countries have not had.

Park rangers have the same incentives for exploiting the commons as everyone else. This is as true in South Africa as in Kenya. Each warden will seek to collect her share of bribes before fellow rangers allow the last elephant to be killed. Absent enforcement, no one has an incentive to refuse a bribe and thereby to conserve the resource, because some other ranger will take the bribe instead. Insufficient supervision of park wardens or their superiors' unwillingness to enforce rules (because of bribes ${ }^{214}$ or a lack of information) enables wardens to take bribes more easily. In such a regime, the allocation of the resource to the government becomes an allocation to the park rangers who reap most of the profits from wildlife, and thus the benefits of wildlife do not redound to the citizens of the nation. Absent a proper alignment of warden incentives with citizen preferences, a system to limit opportunities to bribe wardens will be necessary.

Susan Rose-Ackerman argues that competitive elections may reduce corruption in a political system. ${ }^{215}$ The government of Kenya has been a dictatorship in recent years. The southern African countries, in contrast, do have at least nominally democratic political systems. ${ }^{216}$ These political differences may affect incentives of wardens to protect elephants, and may therefore partially explain the successes of South Africa and the failures of Kenya.

Kenya has been a one-party state since $1969 ;^{217}$ the ruling party's status was constitutionally enshrined in 1982. ${ }^{218}$ Kenyan President Moi was

213. See supra notes $126-30$ and accompanying text: see also Andrei Shletfer \& Robert WV Vishny. Corruption, 108 Q.J. ECON. 599. 599 (1993) (defining "government comuption" as "the sale by govemment officials of government property for personal gain").

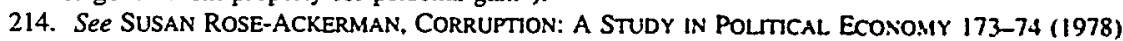

215. Id. at 213.

216. BONNER, supra note 2, at 137-38.

217. THE COMMONWEALTH YEARBOOK 1992, at 231 (1992) (hereinafter COMMONWEALTII) POLMTCAL HANDBOOK OF THE WORLD: 1993, at 433 (Arthur S. Banks ed.. 1993) (hereinafter HANDBOOK]

218. HANDBOOK, supra note 217, at 433: 2 THE EUROPA WORLD YEAR BOOK 1993, at 1646 (34th ed. 1993) [hereinafier EUROPA]. 
reelected unopposed in 1979,1983 , and $1988 .{ }^{219}$ Suppression of political dissidents $^{220}$ as well as press censorship ${ }^{221}$ occurred in the 1980's. One report notes that "the political system allows [government officials] to indulge in trade and purchase property without let or hindrance."222 Kenya is, by most standards, undemocratic.

South Africa, despite the exclusion of nonwhites from government until 1994, has had electoral competition in recent years. In 1987 the majority party received $52.7 \%$ of total votes, and in 1989 , only $48.6 \% .{ }^{223}$ of the 166 seats in Parliament, the majority held 93 and the two opposition parties held a total of $72 .{ }^{224}$ The press is described as "extremely vigorous," 225 although it was subject to censorship while South Africa was in a state of emergency in the late 1980's. ${ }^{226}$ Although South African "democracy" has not, until recently, allowed nonwhites access to the political process, there generally has been more competition for power and a greater degree of media scrutiny of government in South Africa than in Kenya.

Dictatorships reduce government accountability to citizens. The lack of electoral competition often allows government officials to ignore public opinion. Officials in an undemocratic government may more easily seek to increase their wealth ${ }^{227}$ at the expense of the nation's citizens. In Kenya, warden-agents fail to act on behalf of their citizen-principals because they are not held accountable by democratically elected officials. ${ }^{228}$ Although the government of Kenya is supposedly managing national wildlife for the benefit of its citizens, its lack of accountability allows officials to pursue other goals, goals that may be detrimental to the survival of elephants. ${ }^{229}$ In contrast, a government that has potential challengers is forced to address the desires of its citizens in order to remain in power. ${ }^{230}$ Thus its officials will pursue a strategy that accords more closely with the preferences of its citizens. ${ }^{231}$

219. COMMONWEALTH, supra note 217 , at 231 .

220. 2 EUROPA, supra note 218, at 1646; see also 21 AFRICA CONTEMPORARY RECORD B325 (Marion E. Doro ed., 1992) [hereinafter ACR].

221. 21 ACR, supra note 220 , at B330.

222. 21 id. at $\mathrm{B} 327$.

223. 2 EUROPA, supra note 218, at 2568; see also 21 ACR, supra note 220, at B653.

224. 2 EUROPA, supra note 218 , at 2581 .

225. 2 id. at 2583.

226. Id.

227. ROSE-ACKERMAN, supra note 214 , at 231.

228. See JOHN T. NOONAN, JR., BRIBES 704 (1984) ("It is supposed, not unreasonably, that perceptions of political advantage by the accountable officeholder will often coincide with what is the public good. For a bribe there is no accountability but to the briber."); Shleifer \& Vishny, supra note 213, at 601 ("Corrupt officials go unpunished because their bosses often share in the proceeds and because public pressure to stop corruption in most countries is weak.").

229. See ROBERT KLITGAARD, CONTROLLING CORRUPTION 44 (1988) (arguing that when corruption becomes possible, "[o]fficials spend an increasing amount of their time looking for ways to secure bribes and extort payments, rather than exerting themselves in fulfillment of their public duties").

230. See ROSE-ACKERMAN, supra note 214 , at 231-32.

231. Id. at 231 . 
South Africa's officials are more likely to manage elephants in the public interest because they have been challenged for reelection and are therefore more accountable to the desires of citizens.

Because Kenya's dictatorship allows corruption, and because corruption allows park rangers to act on their own behalf, Kenya's poaching problem has been exacerbated. ${ }^{232}$ The gains from elephant killings are captured by park wardens instead of citizens. This stands in contrast to South Africa, where a more responsive government gives the electorate as a whole a say in how its elephant asset should be managed. Because democratic governments that tolerate corrupt rangers can be voted out of power, they have an incentive to prevent bribe taking in order to remain in power. ${ }^{233}$

In South Africa, electoral competition aligns incentives so that the government returns the value of the elephant to the entire nation in the form of improved parks and abundant wildlife. Furthermore, South Africa, unlike Kenya, earned revenue from elephants by selling ivory and hides, thus increasing the total return, and thereby making even more important the fact that its system effectively returned the profits to the people. The South African system gives all citizens an incentive to preserve elephants because everyone stands to gain when elephants are saved from poachers. Because South Africa's government faces competition for reelection, it supervises its wardens more carefully than does Kenya. This reduces corruption and increases the wealth returned to citizens. Because South Africa allows culling and trade in elephants, the amount of money that it earns is significant enough to help protect elephants and to interest the population in the effective management of the resource. By allowing tangible benefits to accrue to citizens, South Africa reduces incentives for killing elephants inefficiently. Like Zimbabwe, the entire

232. A fully effective dictator would manage the natural resources welt. Her incentuves would be to maximize profits, like a private owner, by conserving elephants so that they will regenerale. This, of course. involves eliminating comption within her government. The dictator's efforts to elımınate inımical comuption probably would be stymied by high monitoring costs. See KLTGAARD, supro note 229. al 70-7I ("The principal's problem grows difficult when . . . he has poor information about the agent's actıvitues. either productive or comupt."); see also ROSE-ACKERMAN, supro note 214, at 198-99 (noung that unitike company stockholders, voter-citizens cannot sell their shares in the country): Edward C. Banficld. Corruption as a Feature of Govermmental Organization. 18 J.L. \& ECON. 587.598 (1975) ("Unlike the shareholder, the citizen cannot easily disassociate himself from a comupt organization; to escape it he must incur the costs of moving to another city, state, or country.").

Monitoring costs include the direct costs of monitoring as well as costs to morale from signs of the principal's mistrust. Thus it is sometimes more costly to stop corruption than to allow it. Banfield. supra. at 590. A dictator may not use the resource efficiently for other reasons as well. If she fears being overthrown she may liquidate the resouree quickly while it is still under her control.

233. Another method of curing this agency-corruption problem may be to privaluze. In a privatized scheme, managers will seek to reduce comption to the extent that it consists of taking (but not necessarily making) bribes. ROSE-ACKERMAN, supra note 214, at 191. Zimbabwe's CAMPFIRE program creates a form of property rights in elephants, and in that sense privatizes the animals. Because the owners are the people who directly benefit from successful management, they will have greatly reduced incentuves to take bribes. Roger Cohn, Zambia: The People's War on Poaching. AuduBon. Mar.-Apr. 1994, al 70. 76 (reporung Zambian tribal chief and former poacher who changed his ways once he was given incentuve to retaun wildlife). 
South African community has a stake in preservation because its members stand to profit. Kenyans, in contrast, can gain from elephants only by killing them illegally, and therefore have no incentives to provide protection.

\section{SUCCESSES AND FAILURES OF OTHER BANS ON WildLIFE TRADING}

Part III argued that the CITES ban on ivory trade has prevented Zimbabwe, and other countries using active management policies, from realizing the full benefit of their wildlife policies. The trade ban forces Zimbabwe to forgo vital revenue that it could use to support its protection programs. This Part analyzes the ivory trade ban in light of other bans on wildlife trade. Both the rhinoceros and the leopard have been listed on Appendix I because of their rapidly diminishing numbers. The result of each ban has been quite different, however. The leopard population has stabilized, while the rhinoceros population has continued to plummet. The evidence from these other bans suggests that reliance on the Appendix I complete trade ban for the elephant's protection may be unnecessary or detrimental.

The black rhinoceros population declined from 60,000 in 1970 to an estimated 2000 in $1992 .^{234}$ The horn of the rhino is the prized item, used for dagger handles in Yemen and ground into medicinal products for consumption in China. ${ }^{235}$ The price of horn was $\$ 13,000$ per pound in 1988 , and is thus considerably more valuable than ivory. ${ }^{236}$ Despite the ban, rhinoceros horn has made it onto the black market and thus the poaching continues. ${ }^{237}$ The official trade ban has frustrated active management policies like Zimbabwe's. One estimate suggests that the fee for hunting a single rhino could approach $\$ 100,000 .^{238}$ Such amounts would persuade locals to help protect rhinos from poachers if they had some stake in future profits, but the Appendix I listing eliminates local incentives to preserve the rhino. One rancher in Zimbabwe spends $\$ 22,500$ to protect his seven rhinos each year. ${ }^{239}$ He earns money from tourists, and could support his ranch's protection costs for over four years by allowing just one rhino to be hunted. The ban, however, significantly reduces the value of rhino "assets." Thus the Appendix I trade ban on rhino

234. Bill Keller, Save the Rhinos Safari: Some Say Hunting Could Protect Endangered Species, S.F. CHron., Jan 10, 1993 (Sunday Punch Section), at 4. There are five species of rhinoceros, two of which live in Africa. The black rhinoceros is the most sought after; of the two subspecies of white rhinoceros, the northern white thinoceros is almost completely extinct; and the southern white rhinoceros has recovered substantially over the past 15 years. FITZGERALD, supra note 171 , at 106-07.

235. Keller, supra note 234, at 4.

236. See Glennon, supra note 2, at 26 (citing Jeffrey P. Cohn, Halting the Rhino's Demise, 38 BIOSCIENCE 740 (1988)); Simmons \& Kreuter, supra note 61, at D3 (rhino horn $\$ 8000$ per pound in 1989); see also supra note 59 (ivory prices).

237. Glennon suggests that the comparison of rhinoceros horn to elephant tusks is inapposite, because the small size of the horn and its use in powdered form allows it to be surreptitiously transported more easily than elephant tusks. Glennon, supra note 2, at 26.

238. Keller, supra note 234 , at 4.

239. See Fumbi, Under Guard, THE ECONOMIST, Mar. 5, 1994, at 50. 
products has failed to stop poaching or to halt the decline in the rhinoceros population.

Michael Glennon contends, however, that a trade ban has been more effective in protecting the leopard. The leopard was listed on Appendix I to help stop the trade in its furs. Although it is unclear that the leopard was ever truly endangered, ${ }^{240}$ the ban is credited with having sustained the population. ${ }^{241}$ As a result of the initial success of the ban, the international community has reopened limited trade in leopard skins under a "special quota system" arranged through CITES. ${ }^{242}$ Each country may export a selfdetermined quota, "based on the status of [its] particular leopard population[]."243 The skins may not be intended for resale and each importer is only allowed one skin per year, thereby limiting the development of a sizable commercial trade. ${ }^{244}$ The quota system requires lagging and numbering each skin, as well as annual reports to CITES.245 This allows strict monitoring of the trade so that countries are less able to cheat on their obligation to protect.

The leopard trade system is a compromise designed to recognize that leopards are not equally endangered in all countries. ${ }^{246}$ Because a trophy hunt for a single leopard can reap up to $\$ 10,000,{ }^{247}$ the species provides a potentially lucrative source of funds for additional wildlife protection. The trade system allows countries with stable leopard populations to treat the leopard as a "renewable resource,"248 while other countries continue to provide the necessary protection for the species, assisted by strict international control of trade.

The leopard analogy is perhaps even more apposite than Glennon acknowledges. The trade system developed for the leopard acknowledges the differing needs and capabilities that various nations have for protecting wildlife. It rewards those that have protected the leopard, allowing them to profit from it, and to reinvest the funds in wildlife protection. Meanwhile, those countries in which the leopard is more threatened are able to rely on reasonably effective controls on trade to protect their leopards.

One significant distinction between the cases of the elephant, rhinoceros, and leopard is the ease with which the products are concealed during transportation. A rhino hom can be ground up, and is generally smaller than

240. FITZGERALD, supra note 171 , at 45. The leopard population is "hotly debaled," but one repont estimates that it exceeds 70,000 . Id.

241. See Glennon, supra note 2, at 26 n.219.

242. FITZGERALD, supra note 171 , at 46.

243. Id.

244. Id.

245. Id.

246. Id.

247. Id.

248. Id. 
a tusk. ${ }^{249}$ In comparison, a leopard skin is even more recognizable and sizable than cut ivory. Thus, policing trade in leopard skins may be even easier than policing trade in tusks. Ivory, therefore, probably lies somewhere between the case of the leopard skins and that of the rhino horn in terms of enforceability of a trade ban.

An essential component of the leopard skin system is the strict monitoring of trade flows. Developments in technology will soon allow similar identification of elephant tusks to determine their geographical origin. ${ }^{250}$ Unfortunately, the cost may be high, perhaps $\$ 200$ per tusk, and thus may not provide much help. ${ }^{251} \mathrm{~A}$ reduction in cost, however, would allow ivory from countries with stable elephant populations to be separated from those with declining populations. Such a system might allow a return to a form of regulated trade like the IEQS, which some contend was never given a real chance to work. 252

In 1992, several southern African nations formed the Southern Africa Center for Ivory Marketing (SACIM). ${ }^{253}$ The idea was to create a realistic method of reopening trade in ivory on a limited, strictly regulated basis. SACIM requires that ivory be sold only to approved and registered carvers; that there will be no imports of raw ivory to SACIM countries; and that all profits go directly to elephant conservation. ${ }^{254}$ The critical component of SACIM is a plan to "tag" tusks with a hologram, bar code, and serial number. ${ }^{255}$ The combination of these policies would allow SACIM to guarantee that the ivory was taken only from countries whose elephant populations were thriving. It would therefore allow some countries to resume profiting, while enabling the countries with endangered elephant populations to continue their protection.

The success of the system for regulating the leopard trade suggests that it is possible to design a flexible international trade ban. The system recognizes that some countries are more successful than others at preserving the species, and rewards those countries with more effective preservation systems. It also supports the proposition that trade, if properly managed and monitored, will not necessarily lead to the extinction of a species. Instead such trade can benefit everyone: consumers, local populations, and most important, the species.

249. See supra text accompanying note 237.

250. See, e.g., Concar \& Cole, supra note 4, at 32 (discussing development of isotopic analysis of ivory to determine geographic origin); Nicholas Georgiadis, Fingerprinting Ivory, WILDLIFB CONSERVATION, Mar.-Apr. 1993, at 72, 72-73 (discussing progress toward using genetic differences across regions to determine ivory's origin).

251. Concar \& Cole, supra note 4, at 32. But see Glennon, supra note 2, at 39 (noting existence of inexpensive marking system).

252. See BONNER, supra note 2, at 143.

253. Ricciuti, supra note 1 , at 30 .

254. Id.

255. Cole, supra note 120 , at 7 . 


\section{CONCLUSION}

This Note has shown that a scheme of active management and property rights more effectively creates incentives to preserve a species than does a rigid ban on all trade in the species. The success of active management in southern Africa has resulted in the growth of elephant populations. By allowing local people to share in the profits from elephants, the active management systems give people a reason to protect the elephant. The policy has the effect of removing the elephant from the commons and allocating present and future rights to profit from it to the people. As numerous commentators have shown, similar solutions ameliorate the problem of overconsumption associated with other common resources.

International law, through CITES, has frustrated this goal by eliminating owners' incentives to protect elephants as their own property. The movement of the elephant from Appendix II to Appendix I has removed the legal ability to profit from elephants, and hence diminished the incentives to protect them. The change has forced all of Africa to adopt a protective system that has failed to protect elephants in the countries previously using it. The protective management system reduces citizens' incentive to preserve the elephant species because it reduces their ability to profit from it. Furthermore, corruption in Kenya keeps the few profits that are earned from tourism from being passed through to the average citizen.

Although active species management often involves culling, protective management coincides with an increase in the number of elephants killed by poachers. Culling is superior to illegal poaching because the money earned from the ivory assists other elephants, rather than lining poachers' pockets. ${ }^{236}$ If elephants must die-and ivory demand and expanding human populations have heretofore dictated that they will-active management ensures that their deaths will help to preserve the elephant species. If the CITES complete trade ban produces the same results as the trade ban in Kenya, local populations may

256. Culling may also be preferable because of its effects on the elephants themselves. A cull usually targets an entire herd, typically 30-40 elephants. thereby spanng individual elephants the traums of experiencing the death of other elephants in the herd. See Ricciut. supra note 1. at 28 ("If calves or females are knocked out of a population, the trauma suffered by the survivors disnpts therr social structure and affects their ultimate survival. Poaching has had the same result. Elephants seem to expenence distress when other elephants die and have been seen touching. even fondling. the remauns."). In contrast to culling. a poacher is likely to target only some elephants in each herd. while hitung many herds. leaving the young to suffer without their parents. A poacher earlier this century "was more ruthless and undiscnminaung than the man hunting under license. He could not afford to be scrupulous about immalure and cow elephants: any beast that carried ivory was his prey." WILSON \& AYERST, supra note 8. at 1.40 Similarly, today a poacher is unlikely to choose elephants whose loss will mean the least to the herd. but instead is likely to target only the oldest, tuskiest, male elephants whose ivory is most valuable. See Harlasd, supro note 8. at 21-22. Scientifically managed culling reduces this problem by allowing a proper age and sex distnbutuon to be maintained. See Karen Barnes \& Richard Barnes. A Lost Generation. WILDLuFe Covservation. Mar.-Apr. 1993, at 70, 71 (noting negative future effects of poaching's decimation of specific age group of elephants). 
again resent animals that compete with them for resources and from which they cannot profit. Until the efficacy of protective management programs improves, banning trade in ivory will remain an unfortunate international policy. 